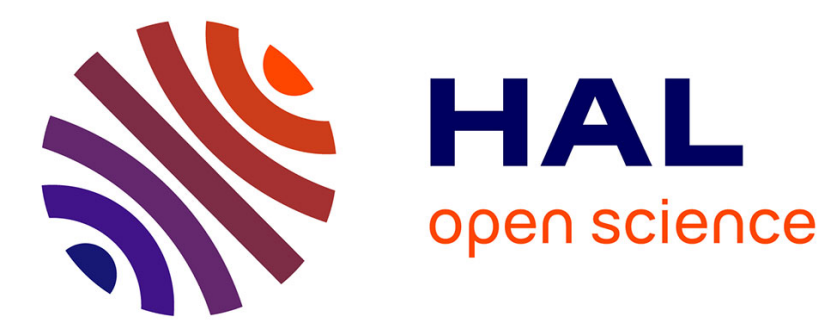

\title{
Conditioning of poultry manure ash for subsequent phosphorous separation and assessment for a process design
}

\author{
Rodolfomarin Rivera, Alexandre Chagnes, Michel Cathelineau, \\ Marie-Christine Boiron
}

\section{To cite this version:}

Rodolfomarin Rivera, Alexandre Chagnes, Michel Cathelineau, Marie-Christine Boiron. Conditioning of poultry manure ash for subsequent phosphorous separation and assessment for a process design. Sustainable Materials and Technologies, 2022, 31, pp.e00377. 10.1016/j.susmat.2021.e00377 . hal03489461

\section{HAL Id: hal-03489461 \\ https://hal.univ-lorraine.fr/hal-03489461}

Submitted on 17 Dec 2021

HAL is a multi-disciplinary open access archive for the deposit and dissemination of scientific research documents, whether they are published or not. The documents may come from teaching and research institutions in France or abroad, or from public or private research centers.
L'archive ouverte pluridisciplinaire HAL, est destinée au dépôt et à la diffusion de documents scientifiques de niveau recherche, publiés ou non, émanant des établissements d'enseignement et de recherche français ou étrangers, des laboratoires publics ou privés. 


\title{
Conditioning of poultry manure ash for subsequent phosphorous separation and assessment for a process design
}

\author{
RodolfoMarin Rivera, Alexandre Chagnes *, Michel Cathelineau, Marie-Christine Boiron \\ Université de Lorraine, CNRS, GeoRessources, F- 54000 Nancy, France
}

\section{A R T I C L E I N F O}

\section{Keywords:}

Ash

Hydrometallurgy

Leaching

Phosphorus

Sulfuric acid

\begin{abstract}
A B S T R A C T
Phosphorus is a strategic resource that cannot be substituted in the foods and pharmaceutical industries. It is an irreplaceable macronutrient for crops, cells, humans and animals. The supply risk can lead to geopolitical problems, and it is urgent to encourage the development of environmentally sustainable recovery technologies of phosphorus from various alternative materials. Poultry manure ash produced inside fluidized bed reactor could constitute an alternative resource of phosphorus to phosphate ores. Therefore, the phosphorus recovery in two representative ash samples has been investigated by combining leaching and solvent extraction under optimal conditions. The mineralogy of these samples has been studied in detail to get relevant information for designing the phosphorus extraction process. Although the relative abundances of phases vary between the two samples, phosphorous is mainly present as a hydroxyapatite mineral and in similar amounts in all particle fractions. Potassium, magnesium, sodium are located in other mineral phases (K-Na-Mg sulfates and $\mathrm{K}$-(Na)-chlorides) mixed with the two main Ca-phases, calcite and hydroxyapatite. The poultry manure ashes were digested by dilute sulfuric acid at liquid-to-solid ratios ranging from $\mathrm{L} / \mathrm{S}=10 \mathrm{~mL} / \mathrm{g}$ to $\mathrm{L} / \mathrm{S}=5 \mathrm{~mL} / \mathrm{g}$. About $90 \mathrm{wt} \%$ of phosphorous in the poultry manure ashes was leached under the optimal sulfuric acid concentration with a liquid-to-solid ratio of $5 \mathrm{~mL} / \mathrm{g}$.
\end{abstract}

\section{Introduction}

Phosphorous (P) is a finite resource and an essential nutrient for living beings. It mainly occurs at mineable grades and tonnages in phosphate sedimentary rock at around $20-50 \mathrm{wt} \% \mathrm{P}_{2} \mathrm{O}_{5}(9-22 \mathrm{wt} \% \mathrm{P}$ ), with Morocco and Western Sahara controlling $77 \%$ of the global reserves $[4,33,38]$. The geological reserves have estimated about 69 million tonnes worldwide, mainly as sedimentary phosphate deposits containing fluorapatite and detrital quartz, clays, and carbonate cements (calcite and dolomite). Igneous phosphate deposits constitute the second type of ore where apatite is the predominant phosphorus-phase, such as carbonatite-alkaline suites, or felsic "Kiruna-type" apatite-magnetite intrusions [19,33].

Mining phosphate rocks production has increased significantly in the last decade, and in 2019, the world phosphate production reached 240,000 t. Phosphate rock is mainly used for the production of mineral fertilisers such as diammonium-phosphate (DAP) and triple superphosphate (TSP), which on average accounts for $74 \%$ of the global inorganic phosphate consumption [13]. As the worldwide demand for crops continues growing, an increasing need for phosphate fertilisers is expected in the upcoming years. However, as the phosphorus grade in phosphate ores continues decreasing, extraction and processing costs also increase [6,28].

Apatite and some rarer phosphates are the primary phosphate rocks used in the production of phosphoric acid $\left(\mathrm{H}_{3} \mathrm{PO}_{4}\right)$ by the so-called wet process, i.e. chemical reaction of the phosphate rock with a mineral acid ([41,42,37,40]). $\mathrm{H}_{3} \mathrm{PO}_{4}$ is the essential chemical used in the fertilizer and food industry, but it has also demonstrated promising results for metal surface treatment $[34,35]$. However, the large quantity of impurities and the gradual reduction of phosphorus concentration in phosphate rocks is detrimental for the economy of current $\mathrm{H}_{3} \mathrm{PO}_{4}$ production routes.

At present, Europe does not produce any raw phosphate ores, and it depends on imports of all raw phosphate and phosphate fertilisers from abroad. At the same time, modern agriculture continues relying on nonrenewable resources. Consequently, the European Union (EU) has considered phosphate rocks as critical raw materials (EU Report COM/ 2014/0297). Phosphorus supply risk can lead to geopolitical problems,

\footnotetext{
* Corresponding author.

E-mail address: alexandre.chagnes@univ-lorraine.fr (A. Chagnes).
} 
and it is urgent to encourage the development of environmentally sustainable recovery technologies of phosphorus from various alternative materials. In this context, the utilisation of ashes produced as byproducts of P-rich residue incineration, such as wastewater treatment sludge, animal manure or animal by-products, biomass ash has been proposed as a sustainable alternative source of phosphorus [2,14,32]. These ashes can have a phosphorus content between 5 and $10 \mathrm{wt} \%$ (11-23 wt $\left.\% \mathrm{P}_{2} \mathrm{O}_{5}\right)$, an order of magnitude less than that present in minerals, and potassium content, which is slightly lower than that present in minerals found in phosphate rocks $(\sim 2 \mathrm{wt} \%)$. The recovery of phosphorus from these materials has the advantage of an eventual decrease in the consumption of natural resources and the environmental and economic impact related to phosphate rocks mining besides eliminating pathogens and toxic organic substances [10,32]. The presence of impurities, such as $\mathrm{Cu}, \mathrm{Zn}, \mathrm{Al}, \mathrm{Si}, \mathrm{Fe}, \mathrm{Mg}$, can be significantly lower $(<1$ wt $\%$ ) compared to naturally occurring phosphate rocks $[17,20,21,26]$. However, certain materials can contain non-negligible amounts of heavy metals such as $\mathrm{Pb}$ or $\mathrm{Cd}$, which must be managed to avoid disseminating in the environment by adding stabilizers [32]. Such features can facilitate phosphorus extraction and other subsequent purification processes. Notice that incineration of residues and the production of ashes rich in phosphorus is readily available, but they are often stockpiled and entail a significant management cost. Phosphorus and potassium should eventually be first separated from the solid matrix to enhance the valorisation of incineration ashes. Dilute sulfuric acid $\left(\mathrm{H}_{2} \mathrm{SO}_{4}\right)$ and hydrochloric acid $(\mathrm{HCl})$ are commonly used to leach phosphorus raw materials and produce phosphoric acid [3,8,15,18,31,39]. However, $\mathrm{H}_{2} \mathrm{SO}_{4}$ is particularly interesting as a leaching reagent for the production of phosphoric acid from raw material containing apatite as calcium released to the leaching solution is drastically reduced by calcium sulfate precipitation [31]. Meanwhile, phosphorus can be recovered from the leaching solution by precipitation of struvite phosphate mineral $\left(\mathrm{NH}_{4} \mathrm{MgPO}_{4} \cdot 6 \mathrm{H}_{2} \mathrm{O}\right)$ or as hydroxyapatite $\left(\mathrm{CaHPO}_{4} \cdot 2 \mathrm{H}_{2} \mathrm{O}\right)[7,8,20,39]$. Although struvite crystallization is the most mature process for phosphorous recovery from aqueous streams [23], the production of $\mathrm{H}_{3} \mathrm{PO}_{4}$ from waste residues is still under development.
This investigation aims to evaluate phosphorus effective leaching from poultry manure ashes produced in a fluidised bed furnace. Firstly, particle size distribution, chemical composition, mineralogy, and morphology were determined to assess the experimental conditions for leaching. Secondly, ash digestion with dilute $\mathrm{H}_{2} \mathrm{SO}_{4}$ was studied by considering different acid concentrations and liquid-to-solid ratios. The optimal conditions for phosphorus recovery from poultry manure ashes were established (high dissolution yield of Phosphorus with the lowest possible acid concentration).

\section{Combustion installation - Production of poultry manure ash in fluidized bed reactor}

Laying hens, manure and ashes were collected from Güres Power Plant (Turkey). Poultry manure was received from laying hens kept in cages where the mixture of excreta and urine, broken eggshells and feathers fell into shallow and finally conveyed out for collection. The manure taken from the poultry farm was about $70 \mathrm{wt} \%$ moisture content, but it was reduced to ca. $20 \mathrm{wt} \%$ by the Organic Rankine Cycle (ORC) [5]. Fig. 1 provides the flowsheet description of the poultry manure combustion system by the biomass power plant of Güres Group.

Fig. 1 initially shows that at the fuel feeding system (point 1), chicken manure with 25-35 wt\% moisture content was fed homogeneously in the fluidized bed gasifier. Chicken manure was gasified and burned with a minimum of $95 \%$ efficiency at $750{ }^{\circ} \mathrm{C}$ in a fluidized bed with partial air (point 2 ). The secondary air supply was used to achieve complete combustion, resulting in a combustion gas that remained at $850-950{ }^{\circ} \mathrm{C}$ for a minimum of $2.5 \mathrm{~s}$ (point 3). The ash-rich gas first passed through the radiation economizer and transferred heat to the thermal oil (point 4). Large particles were then caught under the radiation economizer. The flue gas left at $330{ }^{\circ} \mathrm{C}$, and the particles were trapped into the oil from the cassette type exchanger (point 5).

Automatic cleaners were available on every cassette. The heat transfer of the metal surface temperature was kept below $350^{\circ} \mathrm{C}$. The fly ash in the gas from the oil economizer was held in the cyclone, and the cleaned combustion gas was sent to the air economizer (point 6). The air

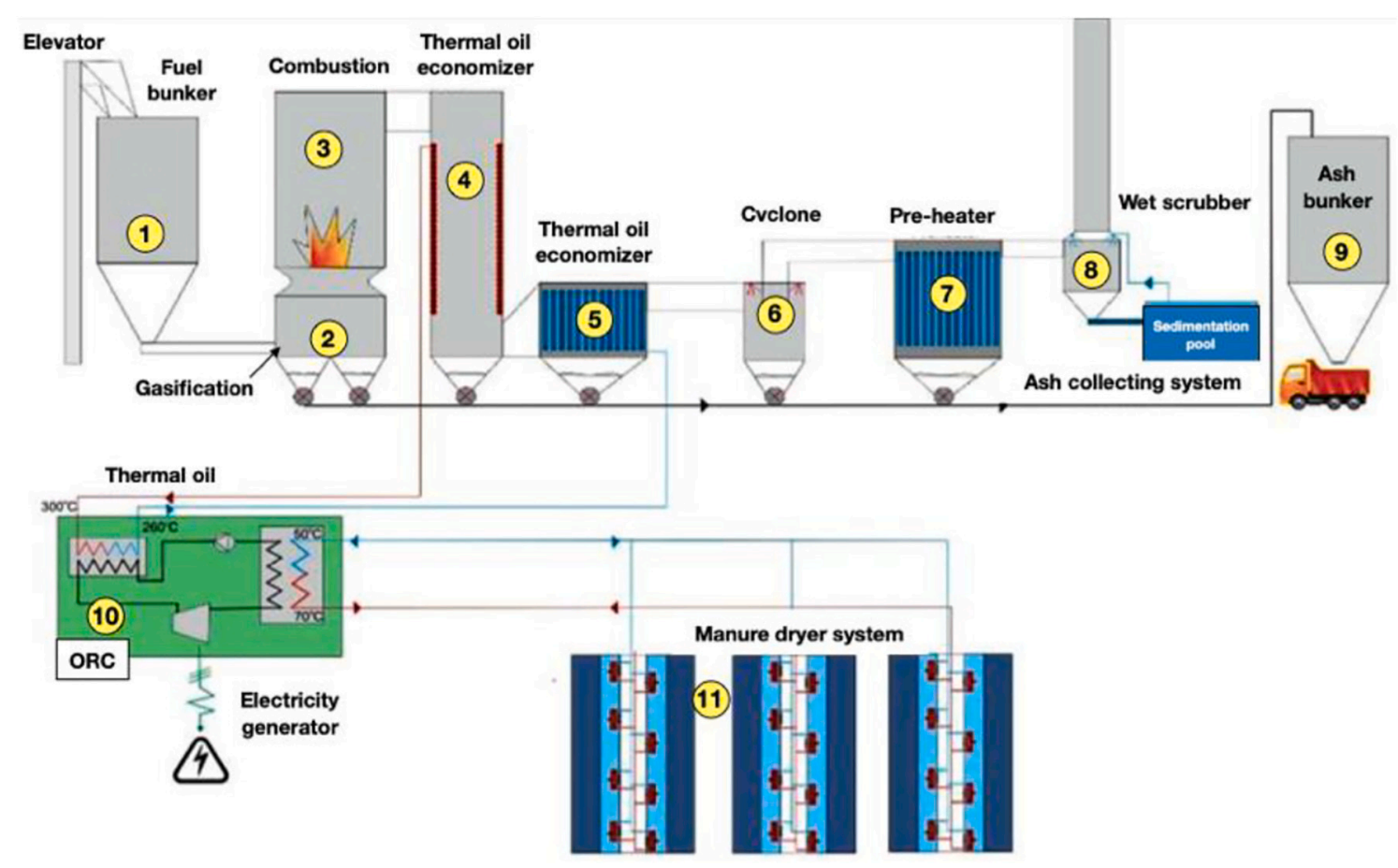

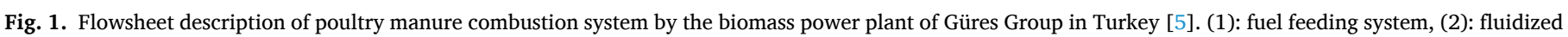

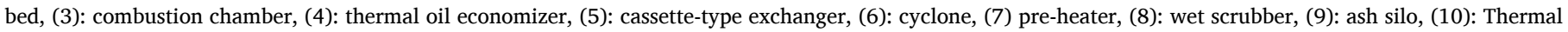
oil, (11): Manure dryer system. 
economizer pre-heated the primary and secondary fresh air to reduce waste gas losses to a minimum. The heated fresh air provided gasification in the fluidized bed and stabilized the combustion reactions at the combustion side (point 7). The flue gas was passed through a wet scrubber, reducing the amount of dust below $50 \mathrm{mg} / \mathrm{Nm}^{3}$ (point 8). The ash from the fuel was collected from many different locations and recovered in the ash silos (point 9). The ash containing high potassium and phosphorus contents was regarded as an organo-mineral fertilizer raw material. The ORC system was used in $19 \%$ of the thermal oil energy for electricity generation, while $81 \%$ was used for closed cycle hot water in manure drying and poultry heating (point 10). The manure drying system used waste heat energy to dry the wet manure. It also ensures the necessary fuel for the co-generation system (point 11).

\section{Materials and methods}

Two types of poultry manure ash were studied: (1) FAECO obtained from the economiser fly ash (point 4 in Fig. 1), and (2) FACYC obtained from the underflow of the cyclone (point 6 in Fig. 1). Both samples were further dried at $105{ }^{\circ} \mathrm{C}$ for $24 \mathrm{~h}$ (moisture content $20-30 \mathrm{wt} \%$ ) upon arrival in the lab. The concentrations of $\mathrm{Mg}, \mathrm{Ca}, \mathrm{K}, \mathrm{Na}, \mathrm{P}, \mathrm{Fe}, \mathrm{Al}, \mathrm{Si}$, and Mn were determined after total digestion by Inductively Couple Plasma Optical Emission Spectroscopy (ICP-OES). A Karl Fischer titration with endpoint detection potentiometry (with two impressed-current indicator electrodes) was used to determine the bulk water content. The samples were calcined at $1000{ }^{\circ} \mathrm{C}$ in a tube furnace under a nitrogen atmosphere, and the released water vapour was transported into the titration vessel for analysis (fully automatic system). The total carbon and sulphur contents were determined by infrared measurement after induction heating with iron, tungsten and tin accelerators on Horiba EMIA-320 V2. The content of organic carbon $\left(\mathrm{C}_{\text {org }}\right)$ was determined by hot etching with dilute hydrochloric acid. The measuring device was the same for caron and sulphur. X-ray powder diffraction (XRD, D8 Discover Bruker) and Scanning Electron Microscope (SEM) were used for mineralogical and chemical determinations.

Ash digestion with mineral acid was carried out with $\mathrm{H}_{2} \mathrm{SO}_{4}$ (95-97\%, Sigma-Aldrich) at liquid-to-solid $(L / S)$ ratios of 10 and 5 in centrifugal tubes (15 mL capacity) under constant agitation using a laboratory shaker (Gerhardt incubator shaker THO500/1) at $200 \mathrm{rpm}$ for $24 \mathrm{~h}$. After agitation, the tubes were centrifuged at $4000 \mathrm{rpm}$ for 4 min to achieve efficient solid-liquid phase separation. The Pregnant Leach Solution (PLS) was filtered using a syringe filter (pore size of 0.45 $\mu \mathrm{m})$ and diluted with 2 vol\% nitric acid $\left(\mathrm{HNO}_{3}\right)$ to determine the concentrations of $\mathrm{Si}, \mathrm{Al}, \mathrm{Mg}, \mathrm{Ca}, \mathrm{Na}, \mathrm{K}, \mathrm{Fe}, \mathrm{Mn}$ and $\mathrm{P}$ using a Microwave Plasma-Atomic Emission Spectrometry (MP-AES, Agilent 4210). The $\mathrm{pH}$ measurements were performed on each PLS before diluting the sample using a pH-meter pHenomenal ${ }^{\circledR}$ pH 1100 L with a pH-electrode pHenomenal ${ }^{\circledR} 221$. The corresponding dissolution yields of elements were calculated according to Eq. (1).

$\%=\frac{\text { Amount of element in the PLS }}{\text { Total amount of metal in the sample }}$

(a)

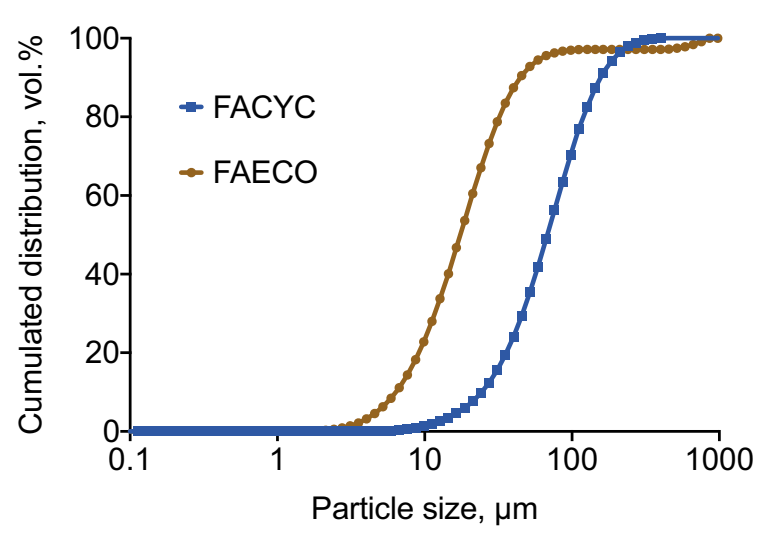

(b)

FAECO

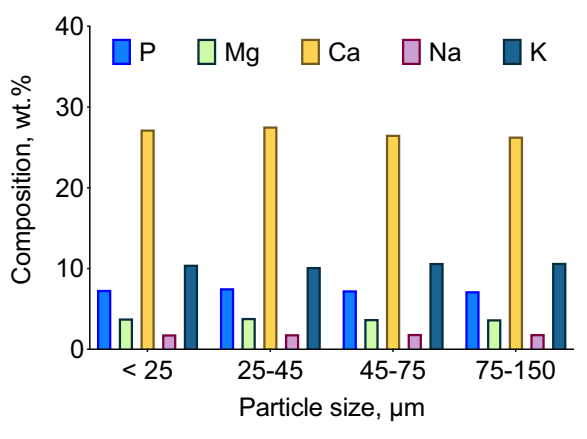

FACYC

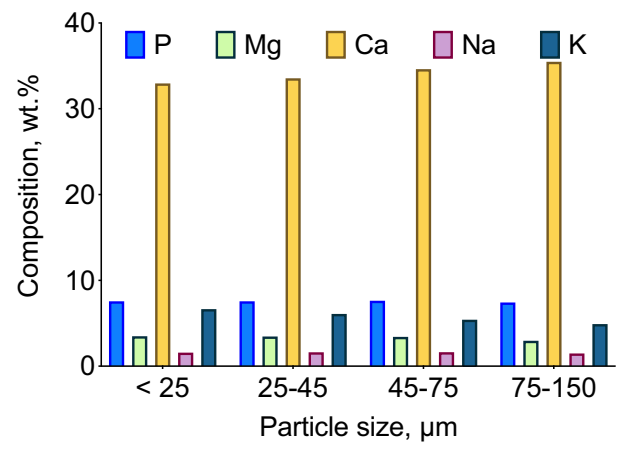

Fig. 2. (a) Particle size distribution (in vol\%) and (b) distribution of major elements (P, Mg, Ca, Na and $\mathrm{K}$ ) in the different fractions for FAECO and FACYC particles. 


\section{Results and discussion}

\subsection{Characterization of poultry manure ashes}

Fig. 2a shows the particle size distribution of both two poultry manure ash samples. FAECO's sample ( $D_{90}=44.7 \mu \mathrm{m}, \mathrm{D}_{50}=17.5 \mu \mathrm{m}$, $\left.\mathrm{D}_{10}=6.4 \mu \mathrm{m}\right)$ was composed of finer particles than FACYC $\left(\mathrm{D}_{90}=157\right.$ $\left.\mu \mathrm{m}, \mathrm{D}_{50}=68.2 \mu \mathrm{m}, \mathrm{D}_{10}=24.3 \mu \mathrm{m}\right)$. Yet, their chemical compositions are slightly different. The chemical composition is very homogeneous, whatever the considered size fraction (Fig. 2b). Ca is the major component in both two samples (26-36 wt\%), followed by $\mathrm{P}(4-8 \mathrm{wt} \%)$ and $\mathrm{K}(6-11 \mathrm{wt} \%)$ (Table 1).

The highest concentration of Ca was observed in FACYC, while the highest concentration of K was found in FAECO. Other elements, such as $\mathrm{Si}, \mathrm{Al}, \mathrm{Fe}$ and $\mathrm{Mn}$, were found with concentrations $\leq 1 \mathrm{wt} \%$. FAECO ash contains $5.6 \mathrm{ppm}, 1.7 \mathrm{ppm}, 15.9 \mathrm{ppm}, 4.3 \mathrm{ppm}$ and $0.9 \mathrm{ppm}$ of As, Cd, $\mathrm{Cr}, \mathrm{Pb}$ and $\mathrm{U}$, respectively. Likewise, FACYC contains $1.2 \mathrm{ppm}, 0.6 \mathrm{ppm}$, $13.4 \mathrm{ppm}, 1.4 \mathrm{ppm}$ and $0.5 \mathrm{ppm}$ of $\mathrm{As}, \mathrm{Cd}, \mathrm{Cr}, \mathrm{Pb}$ and $\mathrm{U}$, respectively. Furthermore, $\mathrm{Zn}$ and $\mathrm{Cu}$ concentrations in FAECO are equal to 279 and $189 \mathrm{ppm}$, and their concentrations in FAECYC are equal to 2433 and 1113 ppm, respectively. Heavy metals present in the FAECO and FACIT ashes will be undoubtedly dissolved in the leach solution. Still, their concentration will be sufficiently low to avoid any the implementation of costly purification steps. These impurities will be transferred in residues, but the concentration will be lower than those found in tailings from phosphate mining and processing.

Therefore, this material is of great interest to produce phosphoric acid as it does not contain high amounts of heavy metals and transition metals, unlike phosphate rocks. It could also be a source of zinc as the concentration is around $1000-2000 \mathrm{ppm}$. However, the grade is much lower than the average grade of most Zn ores, which is about 8-10\%, e.g. around 100 times higher than the measured concentrations. Therefore, the exploitation of such phosphate resources may make the purification/ extraction step of a hydrometallurgical process easier as heavy metal concentrations are low and phosphate content reaches $6 \%$.

Fig. 3 displays SEM-EDX images (Scanning Electron MicroscopyEnergy Dispersive X-Ray Spectroscopy) of FAECO and FAECYC poultry manure ash samples.

The FAECYC and FAECO are composed of particles sized up to $60 \mu \mathrm{m}$ and a few $10 \mu \mathrm{m}$, respectively (images in Fig. 3(i)-a and (i)-b). Fig. 3 shows the presence of calcite $\left(\mathrm{CaCO}_{3}\right)$ and hydroxyapatite $\left(\mathrm{Ca}_{5}\left(\mathrm{PO}_{4}\right)_{3}(\mathrm{OH})\right)$.

In the case of FACYC (Fig. 3(i)), Ca-phosphate was precipitated as a rim covering calcite (Fig. 3 (i)-a). Small hydroxyapatite grains were also found in low particle size fractions $(20-80 \mu \mathrm{m})$. In that case, particles have an irregular shape but tend to be more rounded when particles size is lower than $100 \mu \mathrm{m}$ (Fig. 3(i)-c). FAECO's particles are thinner (5 to 30

Table 1

Concentration of the major elements in the poultry manure ashes (SD: Standard Deviation).

\begin{tabular}{|c|c|c|c|c|c|c|}
\hline \multirow[t]{2}{*}{ Element } & \multicolumn{3}{|c|}{ FAECO } & \multicolumn{3}{|c|}{ FACYC } \\
\hline & wt $\%$ & SD & & wt $\%$ & SD & \\
\hline $\mathrm{Si}$ & 0.7 & \pm & 0.1 & 1.0 & \pm & 0.6 \\
\hline $\mathrm{Al}$ & 0.1 & \pm & 0.0 & 0.1 & \pm & 0.02 \\
\hline $\mathrm{Mg}$ & 3.3 & \pm & 0.1 & 2.7 & \pm & 0.4 \\
\hline $\mathrm{Ca}$ & 23.1 & \pm & 0.9 & 28.3 & \pm & 1.2 \\
\hline $\mathrm{Na}$ & 1.6 & \pm & 0.04 & 1.3 & \pm & 0.1 \\
\hline $\mathrm{K}$ & 9.0 & \pm & 0.6 & 4.8 & \pm & 0.8 \\
\hline $\mathrm{Fe}$ & 0.4 & \pm & 0.3 & 0.2 & \pm & 0.01 \\
\hline Mn & 0.1 & \pm & 0.0 & 0.1 & \pm & 0.02 \\
\hline $\mathrm{P}$ & 6.3 & \pm & 0.3 & 6.2 & \pm & 0.2 \\
\hline $\mathrm{CO}_{2}$ & 34.9 & \pm & 8.7 & 54.1 & \pm & 10.9 \\
\hline $\mathrm{H}_{2} \mathrm{O}$ & 9.6 & \pm & 2.4 & 22.4 & \pm & 4.5 \\
\hline $\mathrm{FeO}$ & 0.8 & \pm & 0.2 & 0.4 & \pm & 0.1 \\
\hline S & 12.1 & \pm & 3.0 & 8.2 & \pm & 1.6 \\
\hline $\mathrm{C}_{\text {org }}$ & 0.2 & \pm & 0.1 & 0.2 & \pm & 0.04 \\
\hline
\end{tabular}

$\mu \mathrm{m})$ and consist mainly of clusters of irregularly shaped particles together with some spherical grains (Fig. 3(ii)). Other elements were present as chlorides $(\mathrm{K}, \mathrm{Na})$, sulfates $(\mathrm{K}, \mathrm{Na}, \mathrm{Mg}$ ), hydroxides $(\mathrm{Ca})$ or oxides (Si). Particles have an irregular shape except rounded grains dominated by apatite (Fig. 3(i)-a and (ii)-c). Chloride compounds (mostly $\mathrm{KCl}$ ) deposited on the edge of particles are euhedral (Fig. 3(i)-b). Rod-shaped silica particles are elongated and constitute isolated particles. $\mathrm{K}, \mathrm{Mg}, \mathrm{Na}$, and traces of $\mathrm{SO}_{4^{-}}$and $\mathrm{Cl}$-based compounds were also found onto the particle surface in both samples as mixed phases of less than a micron in size (Fig. 3(i) and (ii)). Likewise, the deposition of K-, $\mathrm{SO}_{4}{ }^{-}$and $\mathrm{Cl}$-based compounds were also found in some spots. These mineralogical phases were detected by XRD analysis (Fig. 3(ii)-a) and confirmed by Raman spectroscopy. The main compounds containing $\mathrm{Ca}$ are hydroxyapatite $\left(\mathrm{Ca}_{5}\left(\mathrm{PO}_{4}\right)_{3}(\mathrm{OH})\right)$, lime $(\mathrm{CaO})$, calcite $\left(\mathrm{CaCO}_{3}\right)$, and portlandite $\left(\mathrm{Ca}(\mathrm{OH})_{2}\right)$. Furthermore, $\mathrm{S}$ content in both two samples is significant (see Table 1) and corresponds to potassium bearing sulfate (Fig. 3(i) and (ii)) as aphthitalite $\left(\mathrm{K}_{2.25} \mathrm{Na}_{1.75}\left(\mathrm{SO}_{4}\right)_{2}\right)$ and arcanite $\left(\mathrm{K}_{2} \mathrm{SO}_{4}\right)$, which XRD did not detect.

Fig. 4(b) describes the normalized mineralogical compositions of the two samples, which were determined based on the chemical composition depicted in Table 1, as well as XRD and SEM-EDX analyses.

Hydroxyapatite is the main mineral phase in both samples (ca. $38 \pm$ $2 \mathrm{wt} \%$ ), followed by calcite (19-23 wt\%). The calculated amount of portlandite is higher in FACYC than in FAECO due to the relatively high content of $\mathrm{OH}$ (expressed in the bulk $\mathrm{H}_{2} \mathrm{O}$ content in the Table) and $\mathrm{Ca}$ (see Table 1). Its content in FACYC decreases with the decrease of particle size. Such a trend could occur presumably due to the gradient temperature in the cyclone. The aphthitalite content ranges between 11 and $15 \mathrm{wt} \%$. However, due to the high K-content, the FAECO sample contains more sylvite $(12 \pm 1 \mathrm{wt} \%)$ and arcanite $(1.0 \pm 0.6 \mathrm{wt} \%$, especially in small particle sizes).

\subsection{Ash digestion with a mineral acid}

Phosphorus extraction from ashes can be performed by ash digestion using appropriate reactive such as acids. For instance, Fahimi et al. [16] compared several technologies to recover phosphorus from sewage sludge ashes based on thermo-chemical treatment, wet chemical leaching, and the combination of wet chemical leaching and thermochemical treatment. These authors proposed a new approach to directly evaluate the sustainability of the technologies to recover phosphorus from the secondary waste streams towards the phosphorus extraction from phosphate rock utilizing the sulfuric acid-based wet process. It is generally observed that temperature, resins for cation/ anion exchange, or some leaching reagents play a crucial role in the sustainability of technology besides the origin of the phosphorus resource. In the case of phosphorus recovery from sewage sludge ashes, these authors demonstrated no general rule to design sustainable technologies for phosphorus extraction from ashes. Still, the origin, the nature and the composition of the feed material are key factors of the environmental impact of a process besides the unit operations implemented in the process. Nevertheless, in all cases, thermo-reductive based dry processes such as Recophos Inducarb and Thermphos appear to be less sustainable than the sulfuric acid-based wet process due to the energy need for inductively thermal heating [16].

Therefore, in the present work, the dissolution of elements from FACYC and FAECO poultry manure ashes was evaluated after ash digestion with dilute $\mathrm{H}_{2} \mathrm{SO}_{4}$ as a leaching reagent. The sludge $\mathrm{pH}$ obtained at two different $\mathrm{L} / \mathrm{S}$ ratios and acid concentration is shown in Fig. 4(a). Both samples resulted in high alkalinity (initial pH 11.7-12.2), but while increasing the acid concentration, FACYC exhibited slightly higher pH-values than FAECO (Fig. 5(a)). The release of hydroxyl anions from hydroxyapatite and portlandite buffers the slurry's $\mathrm{pH}$, particularly in FACYC. Also, different changes in $L / S$-ratios demonstrated a clear difference in the variation at $\mathrm{pH}$ during leaching (see Fig. 5(a)). $L / S$ ratios $<10 \mathrm{~mL} / \mathrm{g}$ allow increasing the consumption of solid material to 
(i)
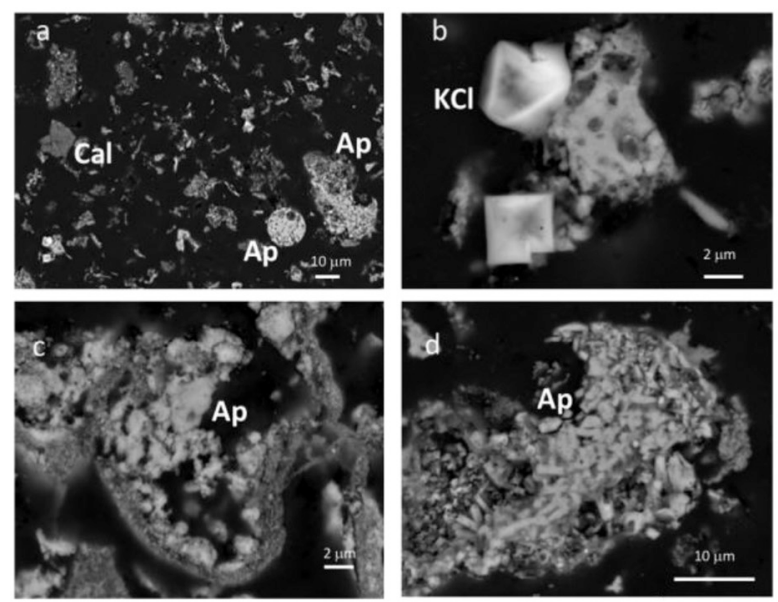

(ii)
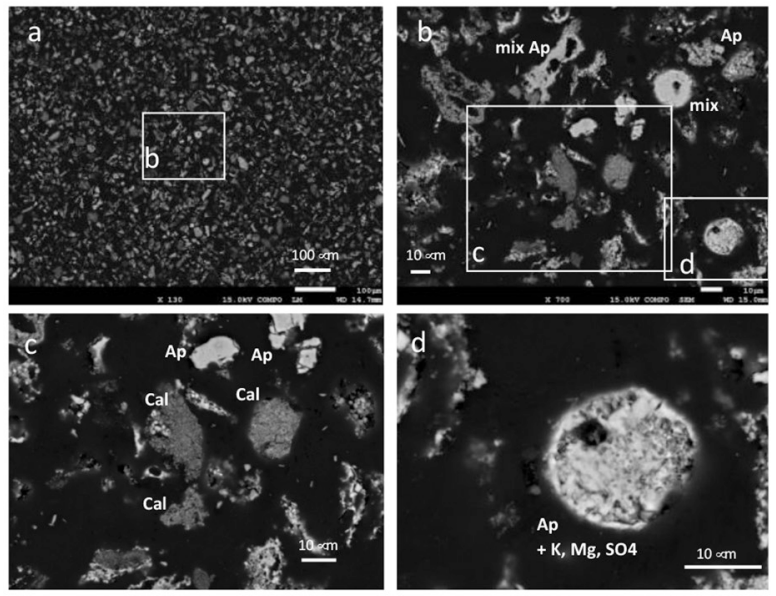

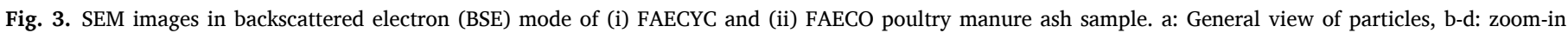
particles showing the different morphologies (Ap: apatite, Cal: calcite).

(a)

C: Calcite $\left(\mathrm{CaCO}_{3}\right) \quad$ P: Portlandite $\left(\mathrm{Ca}(\mathrm{OH})_{2}\right) \quad$ Pe: Periclase (MgO)

$\mathrm{H}$ : Hydroxyapatite $\left(\mathrm{Ca}_{5}(\mathrm{OH})\left(\mathrm{PO}_{4}\right)_{3}\right) \quad$ L: Lime $(\mathrm{CaO}) \quad$ S: Sylvite $(\mathrm{KCl})$
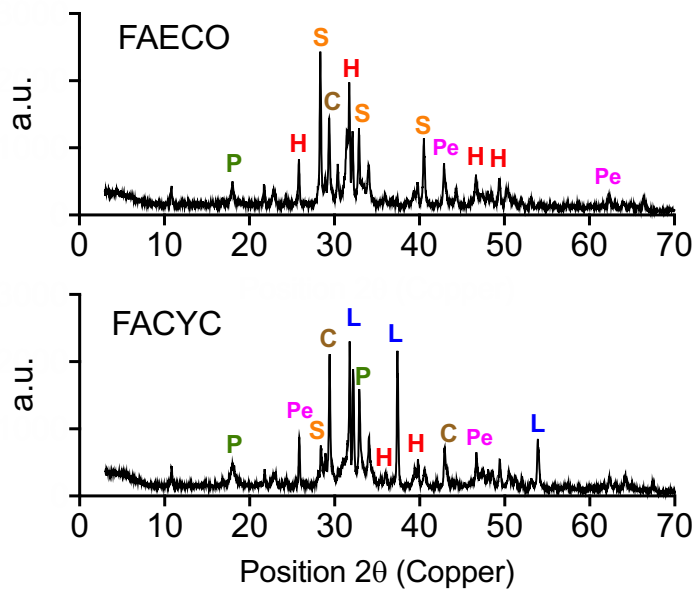

(b)

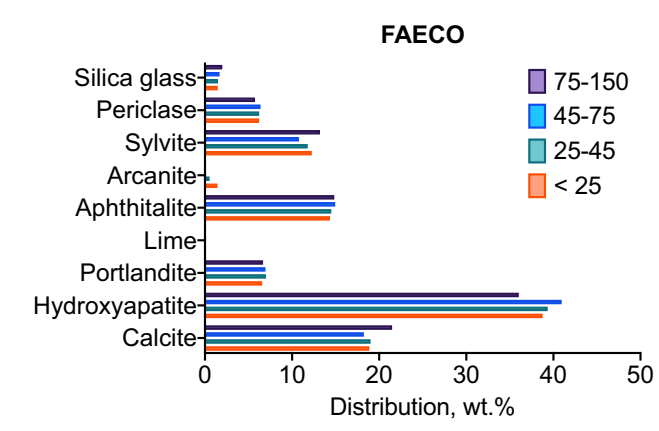

FACYC

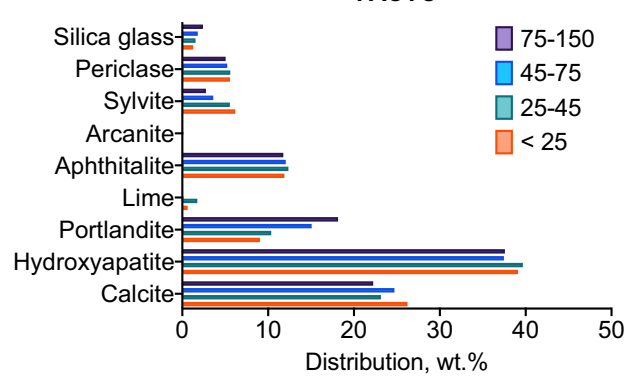

Fig. 4. (a) XRD pattern (a.u.: arbitrary unit) and (b) Normalized mineralogical compositions (to 100 wt $\%$ ) of FAECO-FACYC poultry manure ashes.

enhance the enrichment of $\mathrm{P}$ in solution. However, low $\mathrm{L} / \mathrm{S}$ ratios can limit mass transfers due to an increase in pulp density. Furthermore, low $L / S$-ratios can also enhance the co-dissolution of other impurities. An $L /$ $S=5 \mathrm{~mL} / \mathrm{g}$ is commonly suggested in industrial applications for an optimal solid and liquid streaming handle.

Fig. 5(b) and (c) show the effect of acid concentration on the dissolution rates at $L / S$-ratios of $5 \mathrm{~mL} / \mathrm{g}$ and $10 \mathrm{~mL} / \mathrm{g}$. The dissolution of hydroxyapatite, the only phase to release phosphorus, increased with increasing acid concentration. However, the highest phosphorus dissolution, i.e. the maximum phosphorus concentration in the solution, $[\mathrm{P}]_{\max }$, was reached at a defined acid concentration depending on the $L$ / $S$-ratio. Thus, with an $L / S=10 \mathrm{~mL} / \mathrm{g}$, the $[\mathrm{P}]_{\max }$ for both samples (5-6 $\mathrm{g} / \mathrm{L}$ ) were achieved with an acid concentration of $100 \mathrm{~g} / \mathrm{L}$. Meanwhile, phosphorus concentration in the PLS was multiplied by two when the leaching was performed at $L / S=5 \mathrm{~mL} / \mathrm{g}$ instead of $L / S=10 \mathrm{~mL} / \mathrm{g}$ when using an acid concentration of $150 \mathrm{~g} / \mathrm{L}$ for FAECO $175 \mathrm{~g} / \mathrm{L}$ for FACYC.

By reducing the $L / S$-ratio from $10 \mathrm{ml} / \mathrm{g}$ to $5 \mathrm{~mL} / \mathrm{g}$, phosphorus was enriched in the solution as the ash consumption was doubled. The codissolution of $\mathrm{Na}, \mathrm{Mg}$ and $\mathrm{K}$ phases tended to occur earlier than hydroxy-apatite $(\mathrm{P})$ not only because they are readily soluble in acidic media but also because they are the first to react with the acid as they are deposited onto the surface of phosphorus-rich particles (see Fig. 3(i) and (ii)).

The highest concentration of potassium in PLS (9-17 g/L) is obtained from FAECO digestion as potassium content in FAECO is higher than in FACYC, yielding a higher concentration in solution. Most of the $\mathrm{Al}, \mathrm{Fe}$ 


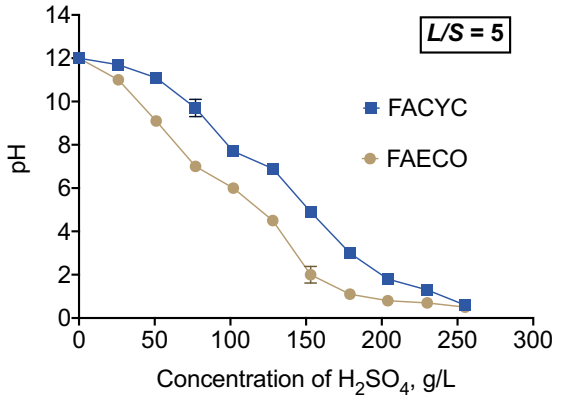

FACYC
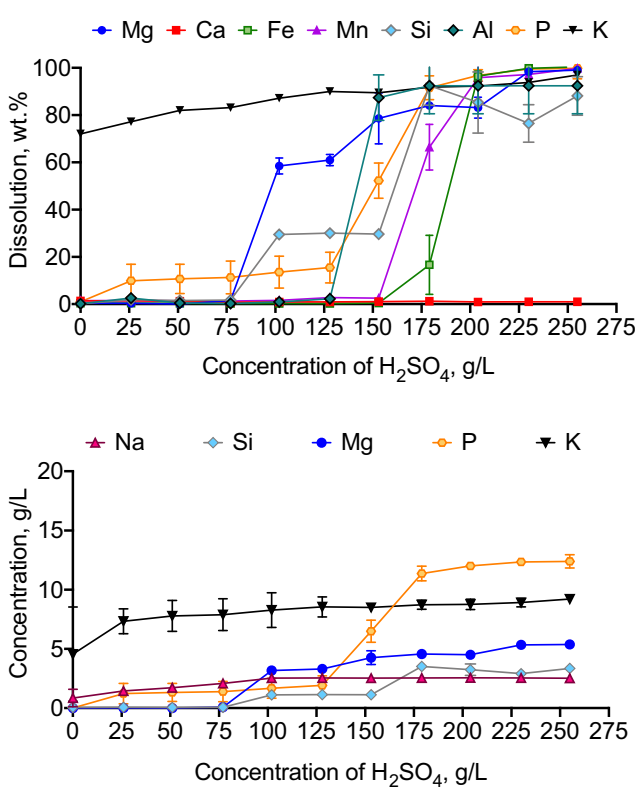

(a)

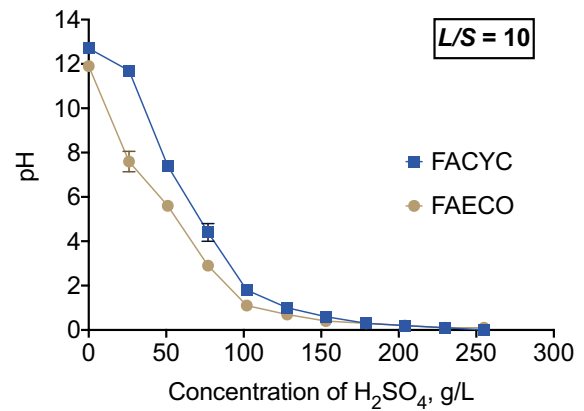

(b)

\section{FAECO}
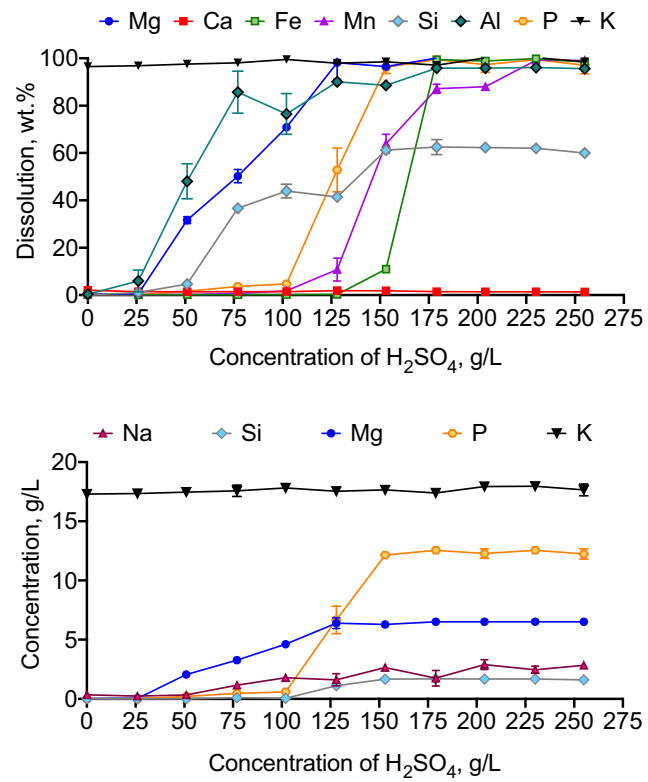

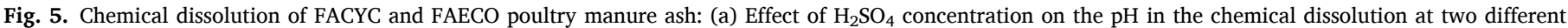

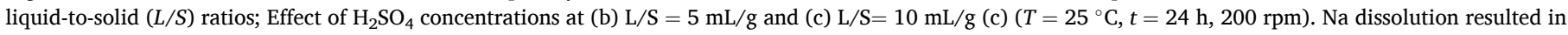
$100 \mathrm{wt} \%$ in the whole range of acid concentration. Concentrations of $\mathrm{Ca}, \mathrm{Al}, \mathrm{Fe}$ and $\mathrm{Mn}<1 \mathrm{~g} / \mathrm{L}$ are not shown to improve readability.

and $\mathrm{Mn}$ phases were co-dissolved, but their concentrations were lower than $1 \mathrm{~g} / \mathrm{L}$. Meanwhile, more than $40 \mathrm{wt} \%$ of $\mathrm{Si}$ was co-dissolved at a relatively high acid concentration $\left(>75 \mathrm{~g} / \mathrm{L} \mathrm{H}_{2} \mathrm{SO}_{4}\right)$, but its solution concentration did not surpass $5 \mathrm{~g} / \mathrm{L}$. Presumably, the dissolution of silica-rich particles $(\mathrm{Si})$ is related to the dissolution of $\mathrm{Na}$ rich glass.

The chemical decomposition of hydroxyapatite in acidic media may occur in several steps through the intermediate formation of $\mathrm{Ca}_{3}\left(\mathrm{PO}_{4}\right)_{2}$ and $\mathrm{CaHPO}_{4}$ (reactions (4)-(6)) [11,12]. Further reaction of these compounds with $\mathrm{H}_{2} \mathrm{SO}_{4}$ led to $\mathrm{CaSO}_{4}$ and $\mathrm{H}_{3} \mathrm{PO}_{4}$, as described by reactions (6)-(7). Likewise, other Ca minerals, such as calcite and lime, also tend to form $\mathrm{CaSO}_{4} \cdot 2 \mathrm{H}_{2} \mathrm{O}$ (reactions (8) and (9)), which exhibits low solubility and, consequently, precipitates [31]. Despite relatively high Ca content in samples, the Ca concentration in the PLS remains low due to gypsum precipitation $\left(\mathrm{CaSO}_{4} \cdot 2 \mathrm{H}_{2} \mathrm{O}\right)$.

$$
\begin{aligned}
& \mathrm{Ca}_{5}\left(\mathrm{PO}_{4}\right)_{3} \mathrm{OH}+\mathrm{H}_{2} \mathrm{SO}_{4}+\mathrm{H}_{2} \mathrm{O} \rightarrow \mathrm{Ca}_{5}\left(\mathrm{PO}_{4}\right)_{3} \cdot\left(\mathrm{H}_{2} \mathrm{O}\right)^{+}+\mathrm{H}_{3} \mathrm{O}^{+}+\mathrm{SO}_{4}^{2-} \\
& \mathrm{Ca}_{5}\left(\mathrm{PO}_{4}\right)_{3} \cdot\left(\mathrm{H}_{2} \mathrm{O}\right)^{+} \rightarrow 3 \mathrm{Ca}_{3}\left(\mathrm{PO}_{4}\right)_{2}+\mathrm{Ca}^{2+}+2 \mathrm{H}_{2} \mathrm{O} \\
& \mathrm{Ca}_{3}\left(\mathrm{PO}_{4}\right)_{2}+\mathrm{H}_{2} \mathrm{SO}_{4} \rightarrow \mathrm{CaSO}_{4}+2 \mathrm{CaHPO}_{4} \\
& \mathrm{CaHPO}_{4}+\mathrm{H}_{2} \mathrm{SO}_{4} \rightarrow \mathrm{CaSO}_{4}+\mathrm{H}_{3} \mathrm{PO}_{4}
\end{aligned}
$$

$\mathrm{CaCO}_{3}+\mathrm{H}_{2} \mathrm{SO}_{4}+\mathrm{H}_{2} \mathrm{O} \rightarrow \mathrm{CaSO}_{4} \cdot \mathrm{H}_{2} \mathrm{O}+\mathrm{H}_{2} \mathrm{CO}_{3}$

$\mathrm{CaO}+\mathrm{H}_{2} \mathrm{SO}_{4}+\mathrm{H}_{2} \mathrm{O} \rightarrow \mathrm{CaSO}_{4} \cdot 2 \mathrm{H}_{2} \mathrm{O}$

\section{Conclusions}

The leaching of poultry manure ashes produced in a fluidised bed furnace was investigated to extract phosphorus. FAECO's ash particles were formed at higher pressure and temperature than FACYC's ash particles, which led to the production of ashes with different particle sizes. Hydroxyapatite is the main mineral phase in both two samples and the unique phosphorus bearer. $\mathrm{Ca}$ is present as calcite, portlandite and hydroxyapatite. These phases are mixed with alkali metals sulfates (K, $\mathrm{Na}(\mathrm{Mg})$ : arcanite-aphthitalite series), chlorides (K (Na): predominant sylvite), and minor periclase. Elemental analyses showed the presence of high content of zinc and relatively high content of copper besides the presence of heavy metals such as $\mathrm{Pb}, \mathrm{Cr}, \mathrm{U}$, as well as As. Nevertheless, the concentration of these metals remains very low compared to typical concentrations in phosphate rocks. As a conclusion, poultry manure ash as a phosphorus source is of great interest from an economic and environmental viewpoint since no complex purification operation will be 
FACYC
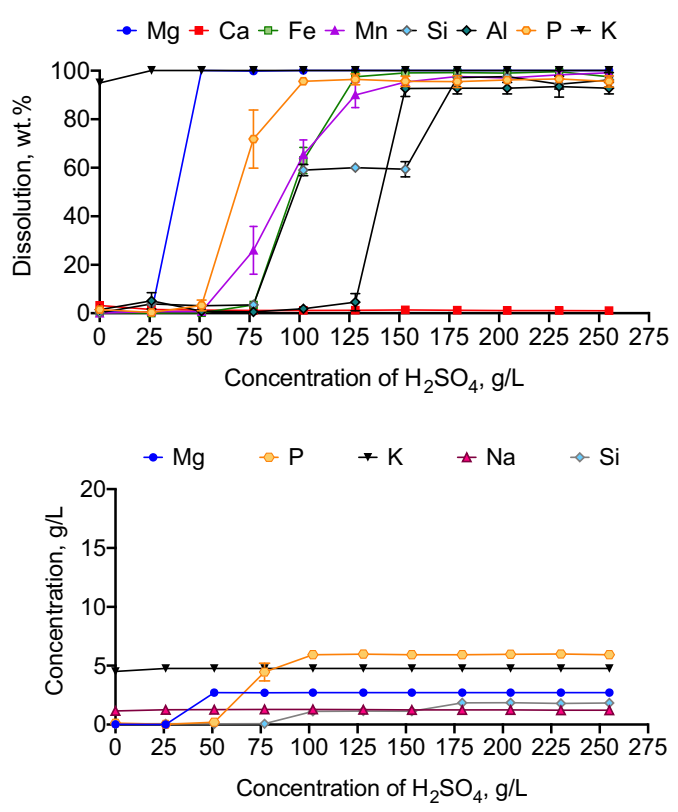

(c)

FAECO
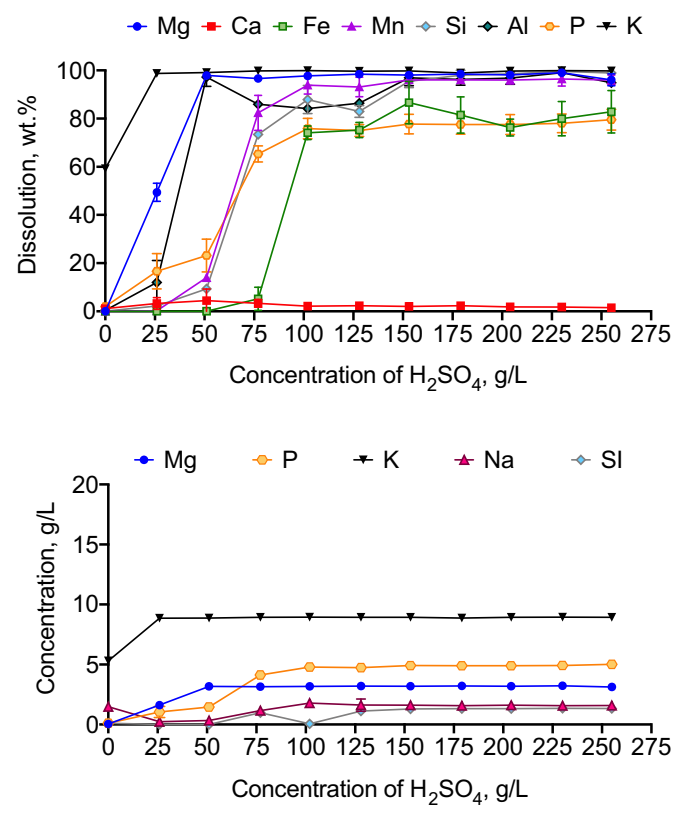

Fig. 5. (continued).

requested after ash digestion and waste treatment will be facilitated.

During ash digestion, as expected, $\mathrm{Na}$ and $\mathrm{K}$ were entirely dissolved. Meanwhile, the dissolution of phosphorus increased with increasing acid concentration. Thus, the phosphorus concentration in solution at an $L / S=5 \mathrm{~mL} / \mathrm{g}$ was twice the P-concentration obtained at $L / S=10 \mathrm{~mL} / \mathrm{g}$ when using a slightly high acid concentration (150-175 g/ $\left.\mathrm{L} \mathrm{H}_{2} \mathrm{SO}_{4}\right)$. The high content of $\mathrm{K}$ in FAECO yielded a higher concentration in solution (9-17 g/L), particularly at $L / S=5 \mathrm{~mL} / \mathrm{g}$. Fe and $\mathrm{Mn}$ also tended to be codissolved, but their concentrations in solution were lower than $1 \mathrm{~g} / \mathrm{L}$.

\section{Author statement}

Funding acquisition: M.C; Supervision: A.C.; Methodology: R.M.R, A. C. and M.C.; Investigation: R.M.R; Formal analysis: R.M.R, M.C., M.C.B.; Writing-original draft: R.M.R., A.C.; Writing-review \& editing: R.M.R, A. C., M.C., M.C.B

\section{Declaration of Competing Interest}

The authors declare that they have no known competing financial interests or personal relationships that could have appeared to influence the work reported in this paper.

\section{Acknowledgements}

This work was carried out under the framework of the ERAMIN project DEASPHOR (Design of a product of Substitution of phosphate rocks) funded by ADEME (AGDI_161873_01_111). The Authors thank the Güres Group, especially Dr. Hayati Olgum, for providing the poultry manure ashes. Dr. Bruno Valentim sent us sieved material prepared in collaboration with Ario Fahimi, who has undertaken a preliminary characterization of the ashes.

\section{References}

[2] A. Amann, O. Zoboli, J. Krampe, H. Rechberger, M. Zessner, L. Egle, Environmental impacts of phosphorus recovery from municipal wastewater, Resour. Conserv. Recycl. 130 (2018) 127-139, https://doi.org/10.1016/j.resconrec.2017.11.002.
[3] M. Atienza-Martínez, G. Gea, J. Arauzo, S.R.A. Kersten, A.M.J. Kootstra, Phosphorus recovery from sewage sludge char ash, Biomass Bioenergy 65 (2014) 42-50, https://doi.org/10.1016/j.biombioe.2014.03.058.

[4] M.A. De Boer, L. Wolzak, J.C. Slootweg, Phosphorus : Reserves, production, and applications, in: H. Ohtake, S. Tsuneda (Eds.), Phosphorous Recovery and Recycling, Springer Nature Singapore Pte Ltd., Singapore, 2019, pp. 75-100.

[5] E. Cebeci, G. Gürlek, T.O. Yilmaz, Disposal of laying manure with bubbling fluidized bed reactor in combined heat and power system, in: I. Dincer, C. O. Colpan, M.A. Ezan, A. Tokuç (Eds.), 7th Global Conference on Global Warming, Izmir, 2018.

[6] D. Cordell, J.O. Drangert, S. White, The story of phosphorus: global food security and food for thought, Glob. Environ. Chang. 19 (2009) 292-305, https://doi.org/ 10.1016/j.gloenvcha.2008.10.009.

[7] J. Dai, W.T. Tang, Y.S. Zheng, H.R. Mackey, H.K. Chui, M.C.M. van Loosdrecht, G. $\mathrm{H}$. Chen, An exploratory study on seawater-catalysed urine phosphorus recovery (SUPR), Water Res. 66 (2014) 75-84, https://doi.org/10.1016/j. watres.2014.08.008.

[8] M. Darwish, A. Aris, M.H. Puteh, M.N.H. Jusoh, A. Abdul Kadir, Waste bones ash as an alternative source of P for struvite precipitation, J. Environ. Manag. 203 (2017) 861-866, https://doi.org/10.1016/j.jenvman.2016.02.033.

[10] S. Donatello, C.R. Cheeseman, Recycling and recovery routes for incinerated sewage sludge ash (ISSA): a review, Waste Manag. 33 (2013) 2328e2340, https:// doi.org/10.1016/j.wasman.2013.05.024.

[11] S.V. Dorozhkin, Inorganic chemistry of the dissolution phenomenon: the dissolution mechanism of calcium apatites at the atomic (ionic) level, Comments Inorg. Chem. 20 (1999) 285-299, https://doi.org/10.1080/ 02603599908021447.

[12] S.V. Dorozhkin, Dissolution mechanism of calcium apatites in acids: a review of literature, World J. Methodol. 2 (2012) 1, https://doi.org/10.5662/wjm.v2.i1.1.

[13] R.J. van Enk, L.K. Acera, R.D. Schuiling, P. Ehlert, J.G. de Wilt, R.J.F. van Haren, The Phosphate Balance : Current Developments and Future Outlook, InnovationNetwork, Utrecht, 2011.

[14] A. Fahimi, F. Bilo, A. Assi, R. Dalipi, S. Federici, A. Guedes, B. Valentim, H. Olgun, G. Ye, B. Bialecka, L. Fiameni, L. Borgese, M. Cathelineau, M.C. Boiron, G. Predeanu, E. Bontempi, Poultry litter ash characterisation and recovery, Waste Manag. 111 (2020) 10-21, https://doi.org/10.1016/j.wasman.2020.05.010.

[15] L. Fang, J. Shan Li, M.Z. Guo, C.R. Cheeseman, D.C.W. Tsang, S. Donatello, C. S. Poon, Phosphorus recovery and leaching of trace elements from incinerated sewage sludge ash (ISSA), Chemosphere 193 (2018) 278-287, https://doi.org/ 10.1016/j.chemosphere.2017.11.023.

[16] A. Fahimi, S. Federici, L.E. Depero, B. Valentim, I. Vassura, F. Ceruti, L. Cutaia, E. Bontempi, Evaluation of the sustainability of technologies to recover phosphorus from sewage sludge ash based on embodied energy and CO2 footprint, J. Clean. Prod. 289 (2021) (2021), 125762, https://doi.org/10.1016/j. jclepro.2020.125762.

[17] S.M. Heilmann, J.S. Molde, J.G. Timler, B.M. Wood, A.L. Mikula, G.V. Vozhdayev, E.C. Colosky, K.A. Spokas, K.J. Valentas, Phosphorus reclamation through hydrothermal carbonization of animal manures, Environ. Sci. Technol. 48 (2014) 10323-10329, https://doi.org/10.1021/es501872k. 
[18] K.J. Hong, N. Tarutani, Y. Shinya, T. Kajiuchi, Study on the recovery of phosphorus from waste-activated sludge incinerator ash, J. Environ. Sci. Heal. Part A 40 (2005) 617-631, https://doi.org/10.1081/ESE-200046614.

[19] E. Jonsson, V.R. Troll, K. Högdahl, C. Harris, F. Weis, K.P. Nilsson, A. Skelton, Magmatic origin of giant "Kiruna-type" apatite-iron-oxide ores in Central Sweden, Sci. Rep. 3 (2013) 1-8, https://doi.org/10.1038/srep01644.

[20] K. Kaikake, T. Sekito, Y. Dote, Phosphate recovery from phosphorus-rich solution obtained from chicken manure incineration ash, Waste Manag. 29 (2009) 1084-1088, https://doi.org/10.1016/j.wasman.2008.09.008.

[21] T. Komiyama, A. Kobayashi, M. Yahagi, The chemical characteristics of ashes from cattle, swine and poultry manure, J. Mater. Cycles Waste Manag. 15 (2013) 106-110, https://doi.org/10.1007/s10163-012-0089-2.

[23] B. Li, I.A. Udugama, S.S. Mansouri, W. Yu, S. Baroutian, K.V. Gernaey, B.R. Young, An exploration of barriers for commercializing phosphorus recovery technologies, J. Clean. Prod. 229 (2019) 1342-1354, https://doi.org/10.1016/j. jclepro.2019.05.042.

[26] L. Luyckx, G.H.J. de Leeuw, J. Van Caneghem, Characterization of poultry litter ash in view of its valorization, Waste Biomass Valorization. (2019), https://doi. org/10.1007/s12649-019-00750-6.

[28] M.C. Mew, G. Steiner, B. Geissler, Phosphorus supply chain-scientific, technical, and economic foundations: a transdisciplinary orientation, Sustain. 10 (2018), https://doi.org/10.3390/su10041087.

[31] L.M. Ottosen, G.M. Kirkelund, P.E. Jensen, Extracting phosphorous from incinerated sewage sludge ash rich in iron or aluminum, Chemosphere 91 (2013) 963-969, https://doi.org/10.1016/j.chemosphere.2013.01.101.

[32] M. Pasquali, A. Zanoletti, L. Benassi, S. Federici, L.E. Depero, E. Bontempi, Stabilized biomass ash as a sustainable substitute for commercial P-fertilizers, Land Degrad. Dev. 29 (7) (2018) 2199-2207, https://doi.org/10.1002/ldr.2915.
[33] P. Ptáček, Phosphate rocks, in: Apatites and their Synthetic Analogues - Synthesis, Structure, Properties and Applications, 2016, pp. 335-381, https://doi.org/ $10.5772 / 62214$.

[34] R. Sánchez-Tovar, M.T. Montañés, J. García-Antón, A. Guenbour, Galvanic corrosion of the base AISI 3161/micro-plasma arc welded AISI 3161 in polluted phosphoric acid media at different temperatures, Int. J. Electrochem. Sci. 6 (2011) 5550-5564.

[35] I. Santana, A. Pepe, E. Jimenez-Pique, S. Pellice, S. Ceré, Silica-based hybrid coatings for corrosion protection of carbon steel. Part I: effect of pretreatment with phosphoric acid, Surf. Coat. Technol. 236 (2013) 476-484, https://doi.org/ 10.1016/j.surfcoat.2012.07.086.

[37] M. Takhim, Process for the Production of High Purity Phosphoric Acid. US 2011/ 0200509 A1, 2008.

[38] U.S. Geological Survey, Mineral Commodity Summaries 2020, United States Geological Survey, Virginia, 2020.

[39] H. Xu, P. He, G. Wang, L. Shao, Phosphorus recovery as struvite from sewage sludge ash, J. Environ. Sci. (China) 24 (2012) 1533-1538, https://doi.org/ 10.1016/S1001-0742(11)60969-8.

[40] C. Ye, J. Li, Wet process phosphoric acid purification by solvent extraction using Noctanol and tributylphosphate mixtures, J. Chem. Technol. Biotechnol. 88 (2013) 1715-1720, https://doi.org/10.1002/jctb.4023.

[41] A. Hannachi, D. Habaili, C. Chtara, A. Ratel, Purification of wet process phosphoric acid by solvent extraction with TBP and MIBK mixtures, Sep. Purif. Technol. 55 (2007) 212-216, https://doi.org/10.1016/j.seppur.2006.12.014.

[42] S. Khorfan, O. Shino, A. Wahoud, Extraction of H3PO4 from wet phosphoric acid by nC4 - nC7 alcohols, Period. Polytech. Ser. Chem. Eng. 45 (2001) 139-148. 